\title{
Crushed rock ballast bed in the railway lines of Lithuania: analysis of the situation and arising problems
}

\author{
Vaidas Ramūnas, Inesa Gailienè, Alfredas Laurinavičius \\ ${ }^{a}$ Dept of Roads, Vilnius Gediminas Technical University, Saulètekio al. 11, 10223 Vilnius, Lithuania
}

\begin{abstract}
Under high cyclic loading of trains the particles of railway ballast disintegrate and worsen in a progressing way. Disintegration of ballast particles is always related to railway track deformations which require expensive continuous maintenance of railway track - the failed ballast is replaced by a new one and is later compacted (tampered).

Railway ballast has a significant influence on the quality and strength of railway track. Therefore, it has been subjected to many specific requirements. Some of them are very important both in structural and cost-efficiency point of view, others are less important or already fully implemented (adapted). The scientists analyse and present research results comprising not only the entire railway transport system but also each of its components.

Seeking to rationally plan further comprehensive research on the ballast bed and materials used in it, the article overviews and systematically discusses the arising problems associated with construction and aggregates of the ballast bed. The article gives the analysis of the functions of crushed rock ballast bed and requirements set to it. Also, studies the results of worldwide scientific researches and need for their adaption to Lithuanian operating conditions. The article presents the research on the condition of railway ballast layers (1514 km) in the railway lines of Lithuania and discusses the results. Additionally the detailed geological studies were carried out in $84 \mathrm{~km}$ in length of ballast bed.
\end{abstract}

Keywords: ballast bed; railway track degradation; structural performance; laboratory tests; fouling.

\section{Introduction}

The operation of railway tracks, also their maintenance, is implemented under limited financing. Therefore, it is of utmost importance to ensure as long as possible service life of all the structural elements of the track and to preserve as good as possible traffic safety with the use of funds available. It is important to set the optimum time for implementing track repair [1], [2]. If periodic repairs are carried out in this way, their costs would be considerably lower, and the total costs of track maintenance would be reduced. It is very important to analyze and adapt to Lithuanian conditions the results of worldwide researches in the field of organizing and optimizing the railway track inspections and repairs.

The ballast has a significant influence on the quality and strength of railway track. Therefore, it has been subjected to many specific requirements [3]. Some of them are very important in both structural and cost-efficiency point of view, others are less important or already fully implemented (adapted). It should be emphasized, that in Lithuania the ballast structure and the materials used in it have been still poorly investigated. Due to the significance of ballast to the quality and strength of the track, it is of particular importance to analyze the existing situation in essence, to determine and systematically discuss the arising problems. This is the first step towards a rational planning of further comprehensive research on the performance parameters of the ballast bed structure (and the mineral materials used).

Aim of the research - according to the accomplished scientific researches and on the documents regulating construction, operation and maintenance of the ballast bed of railway track, to analyze and generalize the functions of ballast bed and the current requirements to it. Also, to determine the quantities and tendencies of mineral materials used for ballast construction and to assess the condition of ballast structures in the railways of Lithuania.

Corresponding author: Vaidas Ramūnas. E-mail address: vaidas.ramunas@vgtu.1t

http://dx.doi.org/10.3846/enviro.2014.164

(C) 2014 The Authors. Published by VGTU Press. This is an open-access article distributed under the terms of the Creative Commons Attribution License, which permits unrestricted use, distribution, and reproduction in any medium, provided the original author and source are credited. 


\section{Research overview on the functions of ballast and its influence over the railway track}

Lithuania is strongly lacking research and scientific approach to the crushed rock ballast structure and the materials used in it. The design solutions are often taken based on the "experience" or the practice of neighbour states. This means that the differences between climatic conditions or operating parameters are ignored. Besides, no innovative technologies are used and this causes backlog in the current Lithuanian railway transport sector compared to the EU railway transport systems from the technical, economic and technological point of view.

Lithuania has neither modern laboratory nor field testing depot for testing railway track structures. In order to use and develop results of the worldwide scientific works it is necessary to invest into modern laboratory equipment already now. This would give a possibility to adapt to Lithuanian conditions and to develop the laboratory testing methods and equipment of triaxial cyclic loading of railway ballast [4-7]. This possibility would allow the scientists under laboratory conditions to obtain testing data corresponding to the real situation in the track, and, certainly, to make experiments by varying different parameters of the track superstructure. Such possibilities are important to Lithuania because of the need to more comprehensively analyse different track superstructures under different environmental conditions and using different materials, since experimenting with the operating railway is unreasonably expensive.

Data obtained with the help of modern laboratory would allow checking and developing the formerly made railway ballast analyses using the discrete element modelling methods [8], [9] which take into account physical and mechanical properties of aggregates. The methods described in those analyses enable to more clearly understand the behaviour of ballast aggregates under cyclic loading.

An accurate prediction of ballast structure degradation requires mathematical model. Hereafter, several scientific works are described relevant to the research of not only ballast but also performance of the whole infrastructure.

In 2000, in Australia an integrated computer-based tool has been developed to predict track behaviour under changing traffic conditions [3]. This railway track degradation model takes into account interactions between track components. The model uses mechanistic relationships and embraces all the major factors which may influence the service life of railway track components. Results of the model application under real conditions revealed that the increasing axle loads and train speeds highly increase track degradation and, in particular, rail wear.

In 2004, in Sweden the results of track maintenance research project were presented. Based on the information collected a prediction model for railway track degradation was developed called DeCoTrack (Degradation Cost of Track). This model simulates the change in track degradation speed (level) depending on the change in traffic parameters, and the output data of the model are: the predicted time period of track serviceability and the costs of eliminating subsequent degradation (maintenance, repairs) in this period. The results of this research project verified the validity of research results obtained in 2000 in Portugal [3] and also an extremely large importance of applying these models in the process of improvement of Lithuanian railway infrastructure maintenance.

Also, in Portugal in the year 2008 an integral method of decision-making on the renewal of railway infrastructure components (more concretely - of ballast bed and rails) was prepared [10]. This method gives two separate LCC (Life-cycle Cost) models for rails and ballast. The rail LCC model uses the earlier developed model, and the ballast LCC model has been newly developed on a basis of the track geometry degradation model.

In 2005, in Australia the research was implemented to analyse real ballast degradation and to determine shortcomings in the currently used methods of measuring the level of ballast fouling. [11]. Those researches and their results are topical in assessing statistical data of ballast layer fouling in Lithuanian railway lines, since up to now an old-fashioned technology was used to measure fouling, it was measured superficially, not accurately and in large significant intervals. And though in 2011 the track control wagon EM140 was acquired and started to be used, technology of measuring the fouling indices remained almost unchanged.

\section{Ballast bed functions and requirements to crushed rock aggregates}

In accordance with the Lithuanian standard LST EN 13450 [12] the ballast bed shall fulfil the following functions:

- to maximally uniformly distribute loads transferred from the wheels to the sleepers and substructure;

- to ensure track stiffness by simultaneously reducing dynamic loads;

- to ensure fixed and stable sleeper position, i.e., to ensure their resistance to horizontal and longitudinal displacements;

- to ensure good water and air filtration in order to increase a service life of sleepers and to preserve the strength of the railway track substructure.

All these functions are fulfilled when the following parameters are properly selected [13], [14]: thickness of ballast layer; cross-section of railway track including the subgrade profile with gradients and the track superstructure;quality of crushed rock aggregates and their compaction level.

The service life and geometry of railway track depend largely on the settlement of ballast layer (especially in an initial period of operation), fouling, stiffness, homogeneity (the same type ballast, the same fraction, without admixtures).

The quality of ballast bed is strongly influenced by fouling level which depends on many factors, such as: ballast of poor quality, service load, lack of drainage; increased amount of fines related to the overloading of substructure; getting of fine fractions into the ballast during freight transportation; railway works and the remaining contamination; environmental factors, and so on. 
When the parameters of rails, ties and sleepers are selected in a proper way, the ballast is the weakest element of the system. In order that the ballast can optimally fulfil its functions, its composition shall comply with the requirements to material homogeneity and grading.

To ensure most favorable conditions to transfer service loads to the substructure, it is necessary to increase the ballast layer thickness (a) under the sleeper beside the rail [13], [14]. The ballast layer thickness must be such as to ensure that the lines of the distribution of loads intersect over the protective layer of subgrade. This is illustrated by the scheme in Fig. 1.

Otherwise, the subgrade areas, getting into the load intersection zone, will take over a larger part of distributed load. For this reason, additional subgrade deformations can occur. Therefore, the analysis of the current situation starts with the measurement of ballast layer thickness and contamination in railway lines (section 6).

Thickness of the ballast layer depends on the distance between sleepers, the width of sleepers and the angle of load distribution $[15,16]$. In accordance with the standards [15-17] it could be stated that under the axle load of $25 \mathrm{t}(\mathrm{P})$, distance between the sleepers $-60 \mathrm{~cm}(\mathrm{n})$ and width of sleeper $-26 \mathrm{~cm}$, the necessary thickness of the ballast layer (a) is $30 \mathrm{~cm}$. In the sections used by fast-speed trains the necessary thickness shall amount to $35-40 \mathrm{~cm}$.

The top width of the ballast bed influences the restraint of horizontal displacements of the sleepers. The higher width of the ballast bed shoulder the larger this restraint. The ballast bed shoulder shall be $35-45 \mathrm{~cm}$ wide on average.

\section{Requirements to the aggregates for railway ballast}

The top width of the ballast bed influences the restraint of horizontal displacements of the sleepers. The higher width of the ballast bed shoulder the larger this restraint. The ballast bed shoulder shall be $35-45 \mathrm{~cm}$ wide on average.

Lithuanian standard LST EN 13450 [15] establishes many requirements to the rocks used for railway ballast. According to the standard the crushed rock used for the ballast shall comply with the following requirements:

- resistance to environmental factors;

- high compressive strength and high impact resistance;

- the ballast shall contain no admixtures which prevent air circulation and water filtration, e.g. loam or other soil admixtures;

- the ballast shall contain no crushed rock elements with sharp ends (sides).

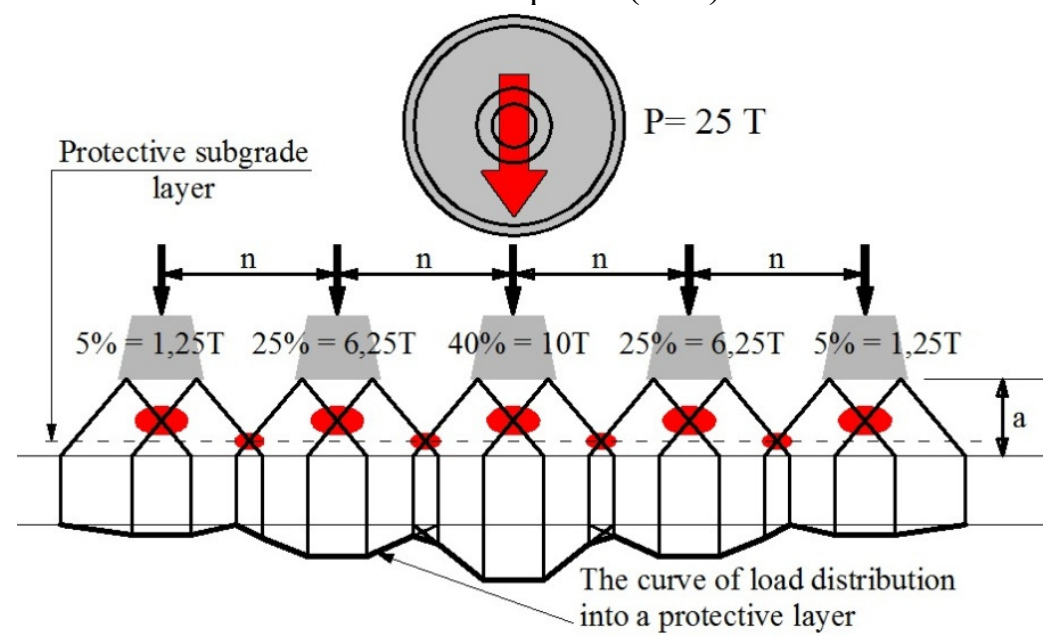

Fig. 1. Load distribution through sleepers in case of concentrated load. P - axle load in tonnes [T]; $\mathrm{n}$ - distance between the axles of sleepers; $\mathrm{a}-$ thickness of the ballast layer.

The mentioned characteristics are verified by certain investigations described in the standard.

The main factors influencing the normal operation of ballast bed is thickness of the ballast layer and the draining properties of subgrade (of them, the cross fall of subgrade). Stability of the ballast bed is strongly influenced by its resistance to transverse displacements, which decreases when the contamination increases.

The greatest reason of ballast self-contamination is the load-induced particle decomposition. Primarily the disintegrated particles increase resistance of sleepers to displacements. But in a course of time under the impact of loads the amount of those particles increases. The smaller particles are additionally formed. Under the impact of load cycles the split-off particles as if envelops the main skeleton-forming particles. In the result, the angle of the internal friction of ballast decreases causing decrease in the ballast resistance to displacements and in ballast stability.

The smallest particles, consisting of loam and clay, are able to penetrate into the ballast bed from the protective layer of subgrade and to increase ballast fouling, i.e. to even more worsen its grading properties. 


\section{Raw materials for railway ballast}

Rocks, intended for the production of crushed rock, are most often extracted in queries in a way of open excavation, however, it sometimes happen that granite is obtained by blasting. When extracting rocks a special attention is paid to extract from those areas where no admixtures of other rocks occur.

Mineral resources of different kinds are distributed unevenly within the territory of Lithuania. Their distribution by kind, amount and detail of exploration within the territory of Lithuanian counties are given in Fig. 2.

The largest amount of resources, found in Lithuania, is the most frequently used gravel and sand, limestone and dolomite. The largest part of explored gravel and sand resources is located in Vilnius, Kaunas, Utena, Alytus and Taurage counties. All the detected deposits of dolomite and limestone are located in the northern part of the country in the territory of Šiauliai and Panevėžys (only dolomite) counties.

Materials for the crushed rock ballast are obtained from the following rocks: basalt, diabase, granite and dolomite. These rocks are the most suitable for the use in crushed rock ballast. Soft rocks, such as dolomite, limestone and other sedimentary rocks, are characterized by the significantly lower compressive strength, therefore, they are not widely used in railway ballast.

The largest part of crushed dolomite excavated in Lithuania is used as crushed rock for construction of roads, however, in recent years it is more and more often used for construction of railway ballast. Basalt, as the construction material, is used in building the substructure of roads and railways. It is intractable material with good compressive strength but not brittle.

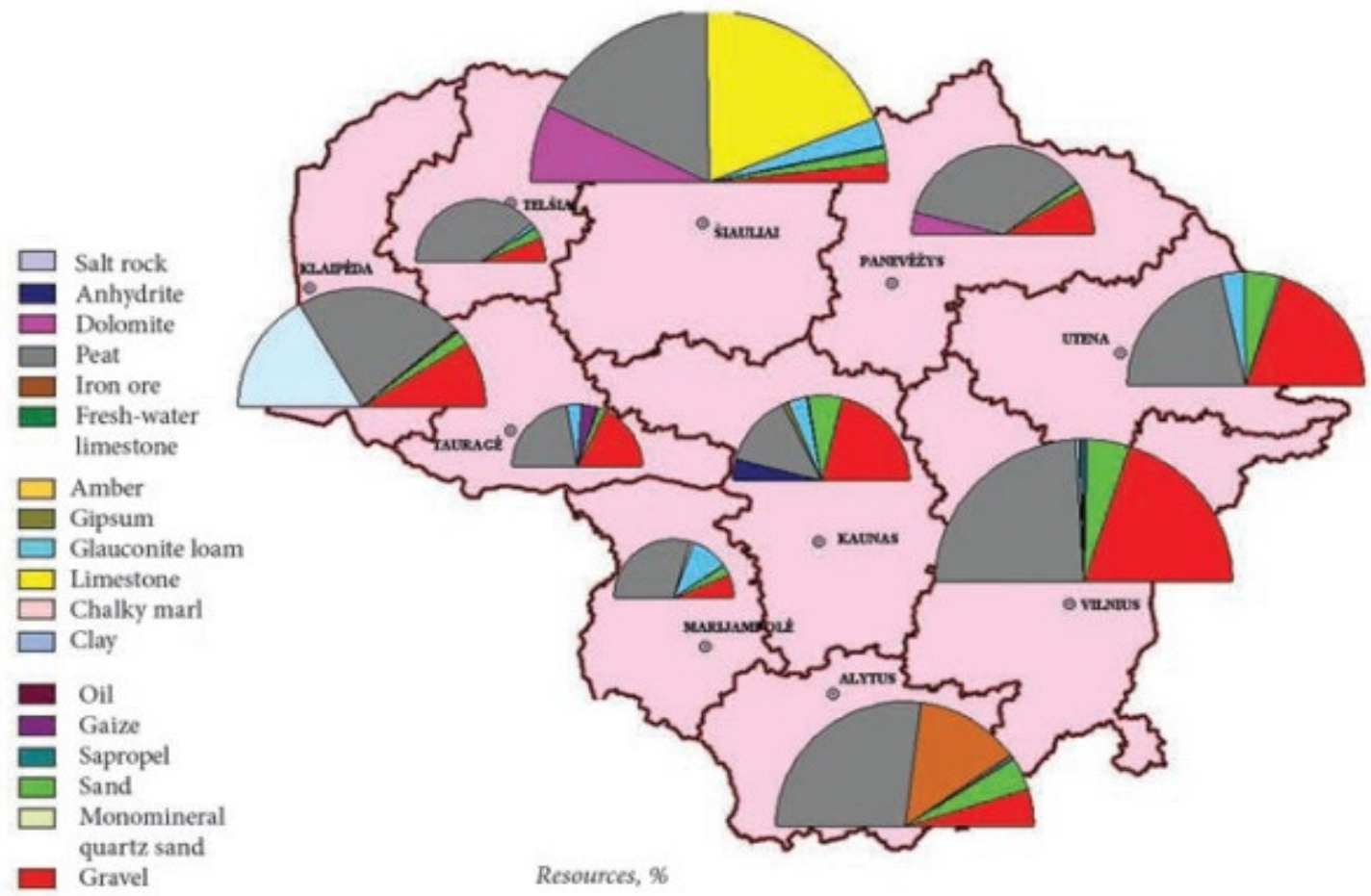

Fig. 2. Mineral resources explored in detail and in general in the counties of Lithuania according to the Lithuanian Geological Survey in 2008 [18]

Basalt, under the effect of continuous sunbeams, starts to step by step degrade. For this reason, basalt is not suitable for many of technical purposes. However this material is not local in Lithuania. Diabase is attributed to igneous rocks. Diabase is distinguished by a relatively good density which is ensured by its average graininess. A compressive strength of diabase is the same or slightly lower than that of basalt.

In Lithuania, railway ballast is mostly constructed from crushed granite. Granite is a coarse-grained igneous rock formed from solidified magma. It is found in many places, though, as a mineral resource worth attention it is found in the southeastern part of Lithuania, in Marcinkonys granitoid batholith that covers an area of about $300 \mathrm{~km}^{2}$. Granite here lies at a depth of 200-300 m, therefore, its extraction has not been started yet due to the large extraction costs. Since Lithuania has no granite queries it is transported from the neighbouring countries - Ukraine and Belarus. Recently increasingly more granite crushed rock arrive from the Scandinavian peninsula.

The quality of crushed stone in Rovinskoje and Zhytomirskoje regions (Ukraine) is very high as it is extracted from the centre of granite core. Belarus is located on the edge of this core, therefore, the crushed stone quality here is slightly worse.

Lithuania uses the crushed granite of grading classes $\mathrm{E}$ and $\mathrm{F}$ [18]. To ensure the necessary fraction of crushed granite transported from foreign countries $(31.5 / 63 \mathrm{~mm})$ it is sieved in Lithuania. Also, the strength tests are carried out to determine the physical and mechanical properties set by the standards. 
Essential information about the measurement of materials properties used in railway ballast is given in the Lithuanian standard LST EN 13450 [12]. It says that the crushed rock shall be resistant to decay (decay is a geological process by which the rocks, soils or minerals decompose under the impact of physical, chemical or biological factors). Water adsorption shall be lower than $0.5 \%$ of the crushed rock mass. If this value is exceeded it is necessary to check a resistance to freeze-thaw cycles, to perform crystallization test and from the results obtained to determine susceptibility to decay.

The crushed rock ballast must have high compressive strength and impact resistance. The crushed rock particles shall also be resistant to fragmentation and abrasion. Appropriate parameters can be determined by Los Angeles method (LA coefficient) in accordance with the standard LST EN 13450 [12]. The lower LA coefficient the better aggregate quality.

Also a very important indicator is grading of the crushed rock ballast. It is determined by sieving aggregates through the sieves with square meshes. In Lithuania, the size of railway ballast particles is set according to the size of sieve meshes representing the following values: $31.5 \mathrm{~mm}$ - minimum value and $63 \mathrm{~mm}$ (it can be also 50) - maximum value.

Table 1. Ballast classes in accordance with LST EN 13450

\begin{tabular}{|c|c|c|c|c|c|c|}
\hline \multirow{4}{*}{$\begin{array}{l}\text { The size of sieve } \\
\text { meshes, mm }\end{array}$} & \multicolumn{3}{|c|}{ Ballast of $31.5 / 50 \mathrm{~mm}$ fraction } & \multicolumn{3}{|c|}{ Ballast of $31.5 / 63 \mathrm{~mm}$ fraction } \\
\hline & \multicolumn{6}{|c|}{ Retained mass, \% } \\
\hline & \multicolumn{6}{|l|}{ Class } \\
\hline & A & $\mathrm{B}$ & $\mathrm{C}$ & $\mathrm{D}$ & $\mathrm{E}$ & $\mathrm{F}$ \\
\hline 80 & 100 & 100 & 100 & 100 & 100 & 100 \\
\hline 63 & 100 & $97-100$ & $95-100$ & 97-99 & $95-99$ & 93-99 \\
\hline 50 & $70-99$ & $70-99$ & $70-99$ & $65-99$ & $55-99$ & $45-70$ \\
\hline 40 & $30-65$ & $30-70$ & $25-75$ & $30-65$ & $25-75$ & $15-40$ \\
\hline 31,5 & $1-25$ & $1-25$ & $1-25$ & $1-25$ & $1-25$ & $0-7$ \\
\hline 22,4 & $0-3$ & $0-3$ & $0-3$ & $0-3$ & $0-3$ & $0-7$ \\
\hline from 31.5 to 50 & $\geq 50$ & $\geq 50$ & $\geq 50$ & - & - & - \\
\hline from 31.5 to 63 & - & - & - & $\geq 50$ & $\geq 50$ & $\geq 50$ \\
\hline
\end{tabular}

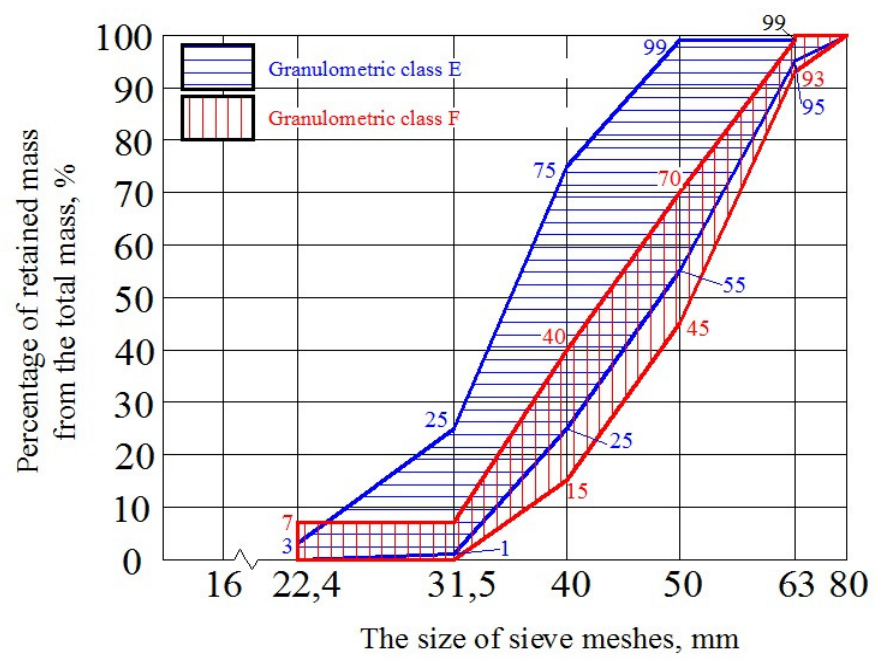

Fig. 3. Sieving characteristic and the permissible grading limits for the crushed rock ballast of $31.5 / 63 \mathrm{~mm}$ fraction and of the grading classes $\mathrm{E}$ and $\mathrm{F}$

The ballast is divided into classes by the residuals on the sieves (Table 1). Figure 3 gives a graphical chart showing a sieving characteristic and the permissible grading limits for the sample of crushed rock ballast of $31.5 / 63 \mathrm{~mm}$ fraction and of the grading classes $\mathrm{E}$ and F. However, it must be emphasized that LA abrasion number and grading (grading classes) are not defined in any normatives of Lithuania. Also there is no clarification why it is necessary to choose $\mathrm{E}$ or $\mathrm{F}$ grading classes.

\section{Research on the amount of mineral materials used and on the fouling indices in the railway tracks operated by the SC “Lietuvos geležinkeliai"}

Recently, when constructing new and reconstructing existing railway tracks the crushed granite is used as the main material for ballast bed. Besides, all the main railway corridors of Lithuania are laid on crushed rock ballast.

Usually, the structure of ballast bed is not studied globally, thus, seeking for the optimum result it is necessary to assess the current railway maintenance technologies(ballast tamping), service loads, quality and safety level, durability and, of 
course, construction cost. However, it is necessary first of all to make the analysis of the crushed rock ballast layer in Lithuanian railway lines which would show a real situation and the existing problems.

The operating length of Lithuanian railway lines is $1767.6 \mathrm{~km}$, of which almost $22 \%$ are made of double-track and multiple-track railways. It is very complicated and expensive to collect comprehensive data about the condition of all tracks, therefore, the main tracks were selected for the research having the highest train traffic and where the issue of maintenance organization is the most topical. Based on the technical passports of tracks, the amount of materials used in ballast construction was determined as well as fouling. The total length of railway tracks used in the analysis of the track superstructure amounted to $1514.315 \mathrm{~km}$.

$86 \%$ of the analysed tracks were constructed with the crushed rock ballast, the remaining $14 \%$ by using sand for the ballast. Fig. 4 gives the diagram of research results.

It was calculated that for the construction of those tracks about $2912000 \mathrm{~m}^{3}$ of crushed rock was used (including graded gravel) and about $353000 \mathrm{~m}^{3}$ of sand. The level of fouling of $785000 \mathrm{~m}^{3}(27 \%)$ of crushed rock ballast and $278000 \mathrm{~m}^{3}$ (79\%) of sand ballast was more than $20 \%$.

It should be noted, that a large amount of railway tracks in railway stations and switches, where the largest ballast fouling and the most rapid fouling process is found, has not been researched yet.

For a more detailed research 3 double-track sections were selected distinguished for a large traffic volume. On those sections, having implemented engineer-geological investigations (the boreholes every $400 \mathrm{~m}$ ), thickness of the ballast layers was determined, as well as fouling.

Section No. 1: Mauručiai-Kazlų Rūda with the length of $17.60 \mathrm{~km}$. The detected average crushed rock layer at the first and second railway track varies between [60-70] $\mathrm{cm}$. Thus, thickness of the crushed rock layer is exceeded by $30-35 \mathrm{~cm}$ on average. In some places of the first railway track the crushed rock layer makes $90-100 \mathrm{~cm}$, at the second track $-80 \mathrm{~cm}$. The upper crushed rock layer, with the average thickness of $43 \mathrm{~cm}$, is not fouled, whereas, the lower crushed rock layer, with the average thickness of $29 \mathrm{~cm}$, is fouled (37.5\% on average).

Section No. 2: Jiesia-Mauručiai, with the length of $10.00 \mathrm{~km}$. The detected average crushed rock layer at the first and second railway track varies between [70-80] $\mathrm{cm}$. Thus, thickness of the crushed rock layer is exceeded by $35-40 \mathrm{~cm}$ on average. In some places of the first railway track the crushed rock layer makes $100-105 \mathrm{~cm}$, at the second track $100-120 \mathrm{~cm}$. On this section the crushed rock layer is integral. The average fouling is $20 \%$.

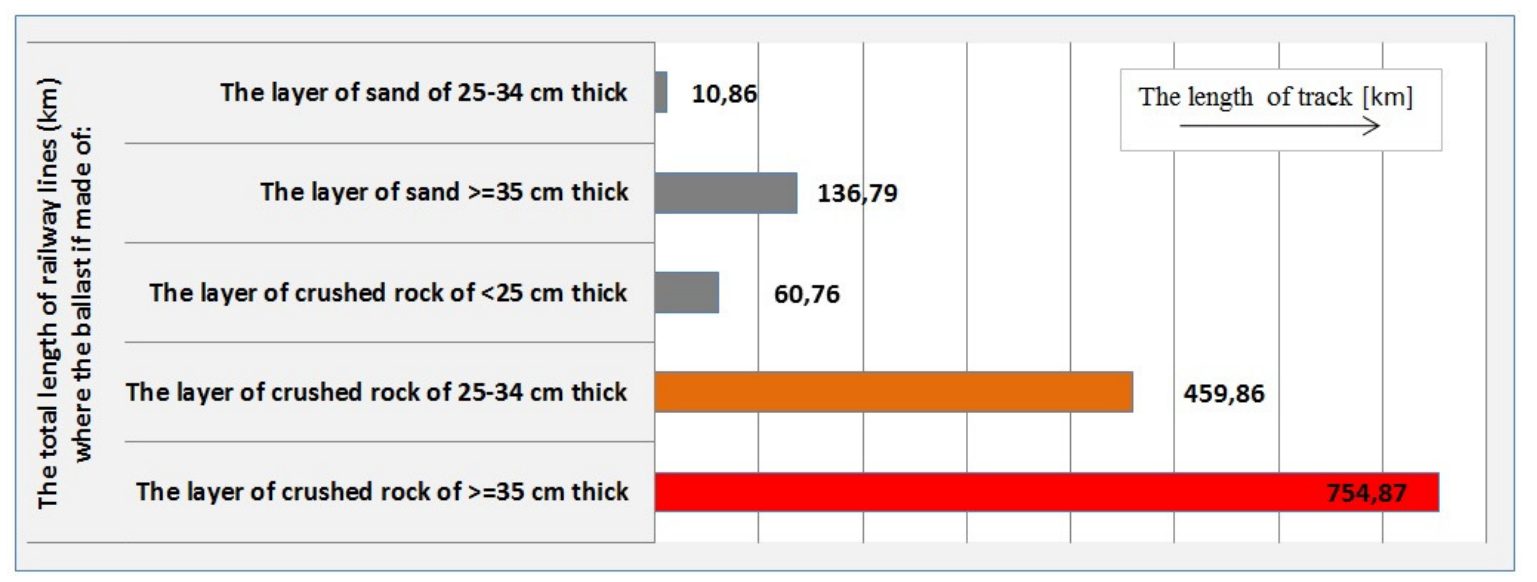

Fig. 4. Distribution in the length of railway tracks by the ballast materials and layer thickness

Section No. 3: Baisogala - Gimbogala, with the length of $14.40 \mathrm{~km}$. The detected average crushed rock layer at the first and second railway track varies between [65-75] cm. Thus, thickness of the crushed rock layer is exceeded by $30-35 \mathrm{~cm}$ on average. In some places of the first railway track the crushed rock layer makes even $140 \mathrm{~cm}$, at the second track $100-110 \mathrm{~cm}$. The upper crushed rock layer, with the average thickness of $49 \mathrm{~cm}$, is not fouled, whereas, the lower crushed rock layer, with the average thickness of $26 \mathrm{~cm}$, is fouled $(25 \%$ on average).

Based on the current standards [18-20] when speed of passenger trains is lower than $160 \mathrm{~km} / \mathrm{h}$ the height of the crushed rock ballast bed, measured in the section under the track, shall amount to $35 \mathrm{~cm}$. However, in the sections under consideration the crushed rock ballast layer is exceeded by $30-40 \mathrm{~cm}$ on average. In some places the ballast layer reaches even 100-140 cm. Taking into consideration the cost of crushed rock and its optimum amount, it becomes obvious that from the cost-efficiency point of view the crushed rock thickness in the sections under consideration is unreasonable and ineffective.

Fig. 5 gives a principle scheme of the problematic situation in the Lithuanian railway track structures where two layers are distinguished: $\mathbf{A}$ - the upper ballast layer (being maintained, cleaned and replaced) and $\mathbf{B}$ - the lower excess ballast layer having formed in a long time due to improperly laid subgrade (poor compaction, improper use of soils). This ballast layer is very much mechanically fouled with disintegrated particles, fine particles of subgrade soils and also outside particles getting into the ballast. The layer has poor draining properties, its stability is unknown. 
The research showed that in Lithuania the largest part of railways has been constructed on the 19th century subgrades. For subgrade formation the soils excavated from cuts and those situated close to the railway were used.

The soils of subgrade were compacted according to the former construction technologies or were completely uncompacted, and gathered resistance during their service life due to the train generated dynamic loads, therefore, on the top of the railway track the soils are better compacted, whereas, deeper and on the edges of subgrade their density has almost unchanged from the beginning of operation.

In many sections under the crushed rock on the upper part of subgrade the sand is dusty, gravelly [SD], more seldom coarse or of medium size. The lower subgrade part is usually laid from the surrounding soils: dusty sand, fine sand [SDo], dusty clay $[\mathrm{MD}]$ and clay of low plasticity $[\mathrm{ML}]$ ranging from the soft-plastic to hard-plastic consistency, and from organogenic sand $[\mathrm{OH}]$.

The largest impact on the subgrades of Lithuanian railways is imposed by the constant waterlogging of the territory and poor condition of water disposal facilities. In lower places almost all the year round and especially in rainy periods water is accumulated which moistens subgrades and decreases their resistance. Due to excess moisture some places at the railway routes are exposed to the bogging processes.

For the above reasons stability of the railway track and durability of the railway superstructure significantly decrease resulting in additional maintenance costs. Owing to improperly laid subgrade and its condition not complying with the requirements, the ballast layer is additionally fouled, settles unevenly and loses its stability.

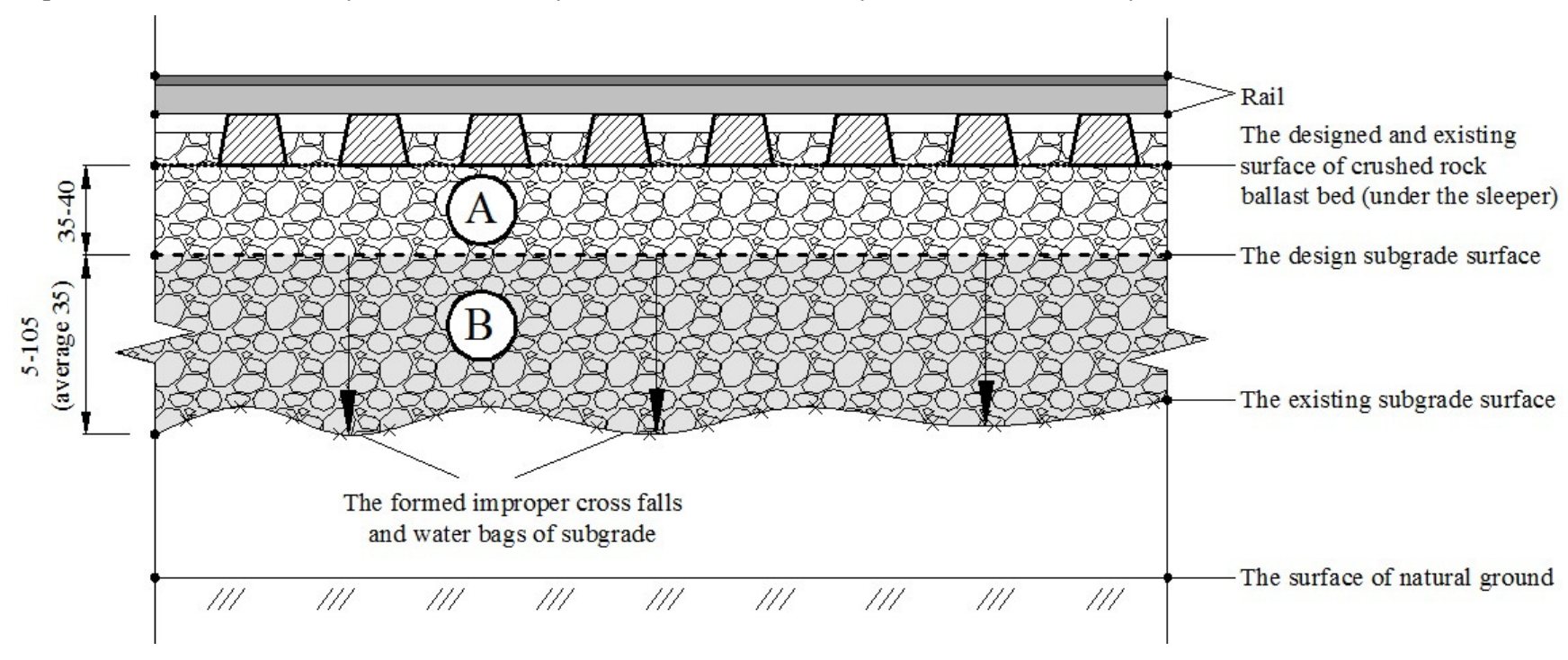

Fig. 5. Principle scheme of the problematic situation in the Lithuanian railway track structures

\section{Conclusions and Recommendations}

It was determined that usually the structure of ballast bed is not studied comprehensively. Lithuania is strongly lacking researches and scientific approach to the crushed rock ballast structure and the materials used in it.

Lack of innovative technologies are used and the design solutions are often taken based on the "experience" and this causes backlog in the current Lithuanian railway transport sector compared to the EU railway transport systems from the technical, economic and technological point of view. Therefore, normatives are necessary to define the ballast selection according to the grading and characteristics of the material. This could lead to considerations if dolomite could be used for the ballast.

Having analysed the functions of ballast bed, the requirements to aggregates for railway ballast, the raw materials and their extraction, there is a need to discover reasons causing changes in the quality of crushed rock ballast during its service life. Seeking for the optimum result it is necessary to assess the current railway maintenance technologies (ballast tamping), service loads, quality and safety level, durability and, of course, construction cost.

Initial analyses showed that in the main tracks (without stations and switches) the fouling level of $785000 \mathrm{~m}^{3}(27 \%)$ of crushed rock ballast and $278000 \mathrm{~m}^{3}(79 \%)$ of sand ballast was higher than $20 \%$.

Analysis of the crushed rock ballast layers in the selected sections of Lithuanian railway lines discovered a real situation and existing problems:

- thickness of the crushed rock ballast layer is exceeded by $30-40 \mathrm{~cm}$ on average, in some places it reaches even $100-140 \mathrm{~cm}$ (exceeding the limit values by 3 times);

- when the crushed rock ballast layer exceeds $1.0 \mathrm{~m}$, its lower part is $30 \%$ more fouled compared to the upper part, and the stability of the lower ballast layer of this fouling is not known.

It is necessary to reduce the amounts of crushed rock used in the ballast (to optimize railway structure by reducing the ballast layer thickness), to take preventive measures for reducing fouling and to select the optimum parameters of ballast bed in order to avoid the excess ballast layer. 


\section{References}

[1] Jovanovic, S. 2004. Railway track quality assessment and related decision making, in Systems, Man and Cybernetics, 2004 IEEE International Conference 6: 5038-5043.

[2] Grimes, C. A. 1995. Application of genetic techniques to the planning of railway track maintenance work, Genetic Algorithms in Engineering Systems: Innovations and Applications. GALESIA. First International Conference: 467-472.

[3] Zhang, Y. J.; Murray, M. H.; Ferreira. L. 2000. Modelling Rail Track Performance: An Integrated Approach, Transport Journal, $187-194$.

[4] Lackenby, J. 2006. Triaxial behavior of ballast and the role of confining pressure under cyclic loading. PhD thesis, University of Wollongong. $260 \mathrm{p}$.

[5] Aursudkij, B. 2007. A Laboratory Study of Railway Ballast Behaviour under Traffic Loading and Tamping Maintenance. PhD thesis. University of Nottingham. 234 p.

[6] Brown, S. F.; Brodrick, B. V.; Thom, N. H.; McDowell, G. R. 2004. The Nottingham Railway Test Facility. in Proceedings of the Institution of Civil Engineers - Transport, 1-14.

[7] Aursudkij, B.; McDowell, G. R.; Collop, A. C. 2009. Cyclic loading of railway ballast under triaxial conditions and in a railway test facility, Granular Matter 11: 391-401. http://dx.doi.org/10.1007/s10035-009-0144-4

[8] Lim, W. L. 2004. Mechanics of Railway Ballast Behaviour, PhD thesis. University of Nottingham. 216 p.

[9] Lu, M. 2008. Discrete Element Modeling of Railway Ballast, PhD thesis. University of Nottingham. 245 p.

[10] Andrade, A. R. 2008. Renewal decisions from a Life-cycle Cost (LCC) Perspective in Railway Infrastructure: An integrative approach using separate LCC models for rail and ballast components. Thesis in Civil Engineering, Technical University of Lisbon. Lisbon. 93 psl.

[11] Ionescu, D. 2005. Ballast degradation and measurement of ballast fouling. Eurailpress, Hamburg, 12-18.

[12] LST EN 13450. 2004. Lithuanian standard. Aggregates for railway ballast (Lietuvos standartas. Geležinkelio balasto skalda). Lithuanian Standards Board. Vilnius: $36 \mathrm{p}$.

[13] Klotzinger, E. 2008. Der Oberbauschotter T1.1: Anforderungen und Beanspruchung, Eisenbahntechnische Rundschau (1/2): 34-41.

[14] Klotzinger, E. 2008. Der Oberbauschotter T1.2: Qualitätsverlauf und Eingriffsschwellen, Eisenbahntechnische Rundschau (1/2): 120-125.

[15] IST 1005384-2:2011. 2011. The upper track structure of the $1520 \mathrm{~mm}$ gauge line, when the passenger train speeds up to $160 \mathrm{~km} / \mathrm{h}$. SC „Lithuanian Railways " standard. Specification. $2^{\text {nd }}$ edition. Vilnius Gediminas Technical University, Building Structures and Materials Research Laboratory (1520 mm vèžès pločio geležinkelio linijos viršutinè kelio konstrukcija, kai keleivinių traukinių važiavimo greitis iki $160 \mathrm{~km} / \mathrm{h}$. Imonès AB „,Lietuvos geležinkeliai “ standartas. Techniniai reikalavimai. Leidimas 2). Vilnius: 15 p.

[16] K/111, Track maintenance rules (Geležinkelio kelio priežiūros taisyklès). Vilnius, Publishing Center: 224 p.

[17] SniP 32-01-95. 2012. Construction norms and regulations. Railways of gauge 1520 mm (СНиП 32-01-95. Строительные нормы и правила. Железные дороги колеи 1520 мм), Moscow: 50 p.

[18] Skrinskas, S.; Gasiūnienè, V. E.; Laurinavičius, A.; Podagèlis, I. 2010. Lithuanian Mineral Resources, Their Reserves and Possibilities for Their Usage in Road Building, The Baltic Journal of Road and Bridge Engineering 5(4): 218-228. http://dx.doi.org/10.3846/bjrbe.2010.30 